\title{
RELIGIOSITY OF STUDENTS WITHIN THE DRC: PRELIMINARY EMPIRICAL FINDINGS
}

\author{
Matthias Gensicke \\ Senior Researcher \\ Sonderforschungsbereich 520 \\ University of Hamburg
}

\begin{abstract}
This article focuses on the preliminary results of a survey that was conducted among 145 students at the Universities of Stellenbosch and Pretoria in October 2002. In this survey the students were asked to answer questions regarding their personal religiosity, their perception of the Dutch Reformed Church (DRC) in the past, present and the future, and the reconciliation process in South Africa, especially with regard to the Truth and Reconciliation Commission. At the end of this article the author highlights certain trends that evolved out of the first evaluation of the survey.
\end{abstract}

\section{Introduction}

As part of the special research project "Changes in Southern African societies and how they are dealt with" located at the University of Hamburg in Germany we are analysing the developments within the Dutch Reformed Church (DRC) in the time-period 1990-2002. As one aspect of this research we are focussing on the younger generation in the DRC. This seems necessary because the youth of today will be the decisive factor for the further development in this church. To get a closer insight of what the youth members in the DRC are thinking and feeling we have just begun doing a quantitative empirical study in Stellenbosch and Pretoria. In a pre-test a questionnaire was handed out to a total of 700 students at the Universities of Stellenbosch and Pretoria in late October 2002. The students were asked to answer questions regarding their personal religiosity, their perception of the $\mathrm{DRC}$ in the past, present and the future, and the reconciliation process in South Africa, especially with regard to the Truth and Reconciliation Commission. In total 145 students responded to this pre-test. The main questionnaire will be handed out in April 2003 to about 12000 students at the University of Stellenbosch and another 5000 students at the University of Pretoria.

This article will concentrate on the main results of the pre-test with a focus on the results of Stellenbosch. In Stellenbosch the questionnaire was handed out to 650 students and 102 were returned. In my interpretation I include observations that I made during the interaction with students. At the end I will highlight general trends that could be picked up from these results. The results presented in this article are only preliminary ones and because of relative small data-basis not valid to make general statements about the youth in the DRC in Stellenbosch. But these results can show important trends and developments within the DRC which will be looked closer at in the main questionnaire. 


\section{Structure of the questionnaire}

The Afrikaans questionnaire that we handed out to the students consisted of the following five main parts which were made up mostly out of multiple choice questions. The five parts were:

1. Personal information to social and religious background of the students.

2. The DRC in the past, present, and future.

3. The reconciliation process in South Africa with special emphasis on the Truth and Reconciliation Commission (TRC).

4. Open essay questions regarding the DRC. Here we deliberately chose the open essay form to allow the students more freedom in answering and also to pick up there individual terminology and diction on certain issues.

5. Questions regarding their personal belief.

\section{The researched group of students}

The group of students we contacted via e--mail is not a simple cross-section of students studying at the University of Stellenbosch. All the students are white Afrikaans-speaking students who are currently members of the Stellenbosch NGK Studentekerk. Most of these students still have regular contact with the Studentekerk and therefore are still relatively positive towards it and have a high level of identification with the DRC student church in Stellenbosch.

The students questioned were in average 22,16 years old and in their $5^{\text {th }}$ semester of studies. $48 \%$ of the students are female and thus giving us a fairly even gender-perspective. For over $90 \%$ of the students the university is the first long-time experience away from their familiar surrounding and influences. Most of the students plan to stay and work in South Africa in the future. They still see a clear perspective for themselves in the country.

Regarding the religious background of the students we have a relatively homogeneous group where $90 \%$ of the students consider their religious upbringing as "traditional" and in close relationship to the DRC. Only $9 \%$ of the students considered their upbringing as "liberal". It is interesting that in Stellenbosch nobody chose the option "charismatic". When talking to the students personally they often indicated to me that they considered "charismatic" to be in a certain sense the same as "liberal" and that they would not differentiate between these two terms.

The students considered their "parents" to be the biggest influence on their religiosity in their upbringing. Another important source were the "friends", followed by the "church" in general and the "pastor", the "school" and "teachers". The "media" had the lowest influence on the students. So far the background of the students. 


\section{The change of religiosity at the university}

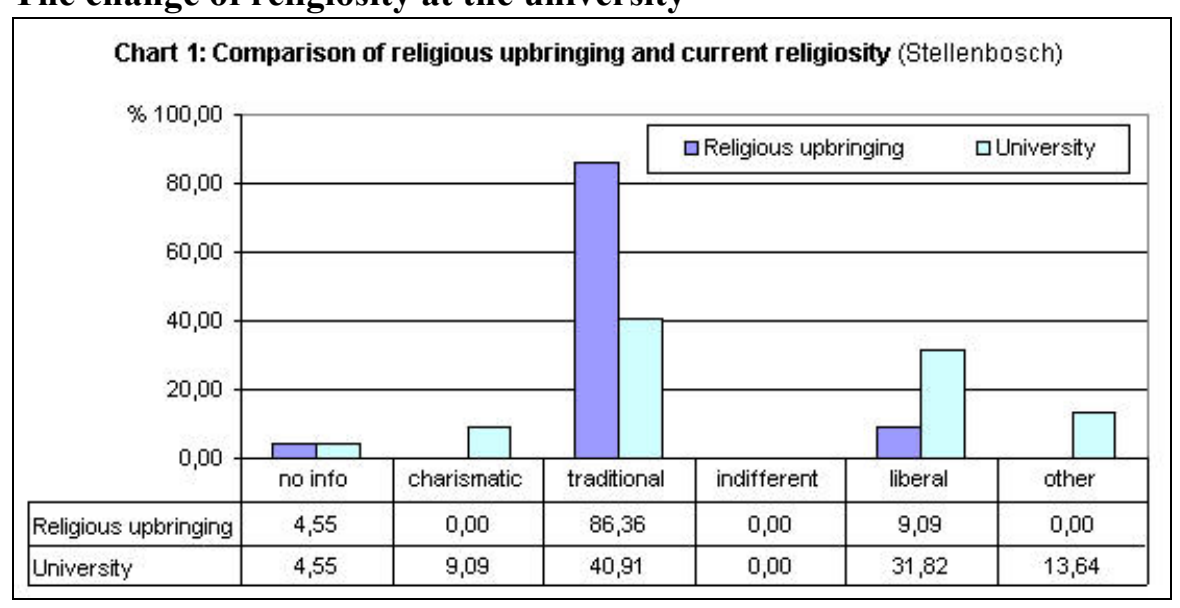

The new more pluralistic environment of the university has a clearly noticeable impact on the religiosity of the students.

The most striking change can be detected in how the students characterise there own current religiosity (see Chart 1). Only $40 \%$ of students compared to before university $86 \%$ would still consider their own religiosity now as "traditional". On the other hand the option "liberal" went up from $9 \%$ to $32 \%$. When asked to explain this shift the students gave comments as:

- "In the beginning I was very fundamental and was bound by regulations without realizing it. After a process of struggling together with friends, I begin to understand the Bible in its context. Faith is not the same as religion" (Male, Stellenbosch).

- "I gained wings and more freedom and I am less bound by rituals and symbols. My eyes were opened half way and I became more of an adult the longer I was a Christian" (Female, Stellenbosch).

- 'I have become more liberal. I have a more open view about being a Christian. I don't see things any longer as either white or black" (Male, Stellenbosch).

Many of the students in Stellenbosch stressed a growing responsibility and maturity in their own faith. An important topic in this regard was a new understanding of scripture and the discovery of alternative forms of worship. Along with the strengthening of their own faith comes a stronger differentiation between their own faith and the more institutionalised forms of religion of the church. Although religion is still for $86 \%$ of the students important in their daily lives, only $68 \%$ of the students in Stellenbosch still feel "much" or "very much" commitment to the church. $22 \%$ felt "not much" or "no commitment at all". This also shows in the church-attendance numbers. The weekly attendance to church services went down from $82 \%$ in there hometown to $68 \%$ at university. Also "only" $63 \%$ of the students claimed to have daily religious practices (like prayers before meals, evening prayer, etc.). 


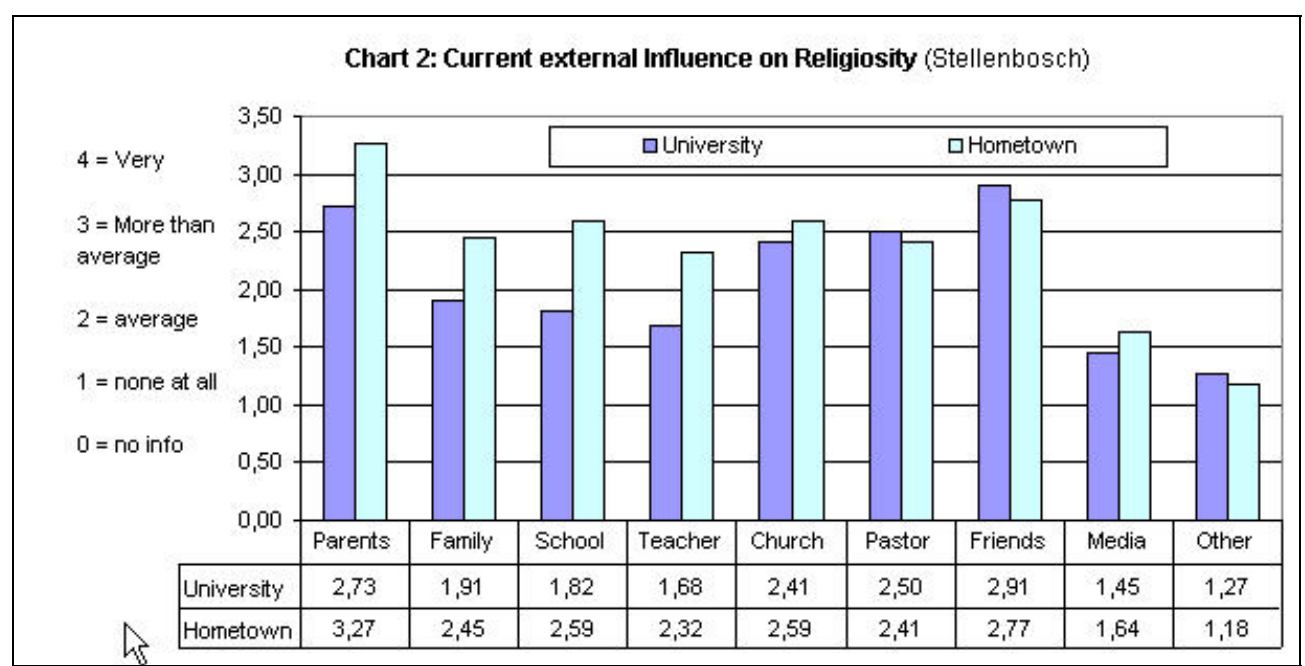

When the students were asked who had the most influence on their current religiosity in all categories the external influence was rated lower in comparison to their upbringing (see Chart 2). The only exception here were the options "friends" and "pastor" which were rated slightly higher than before. The influence of the "parents", "family" and also "the church in general" went down by in average between $10-18 \%$ but were still ranked the highest. This could be an indicator that the students have become more secure and mature in their religiosity. Religion has become a more "personal" thing that does not depend as much on external influences anymore.

It can be summarised that religion still plays a very important role in their personal life, but that the commitment to the church in general has gone down. The differentiation between the personal religion on the one hand and the church on the other has grown. This especially applies for the DRC members. The identification with the DRC has gone down and it is possible now for $18 \%$ of the DRC members to visit other churches, mostly charismatic churches. But in average the students still considered them to belonging to the NGK in the future as very well possible.

\section{The DRC in the past, present and future}

The role of the DRC in the past, present and future was the broad topic of the second set of questions. Bearing the age the students in mind we have to consider that they did not experience the involvement of the DRC actively during apartheid times. Therefore the focus of this block of questions was on the current role of the DRC. But it was still very interesting to question them about what they perceived to be the role of the DRC in the past, referring to the time before 1994 . 


\section{The DRC in the past}

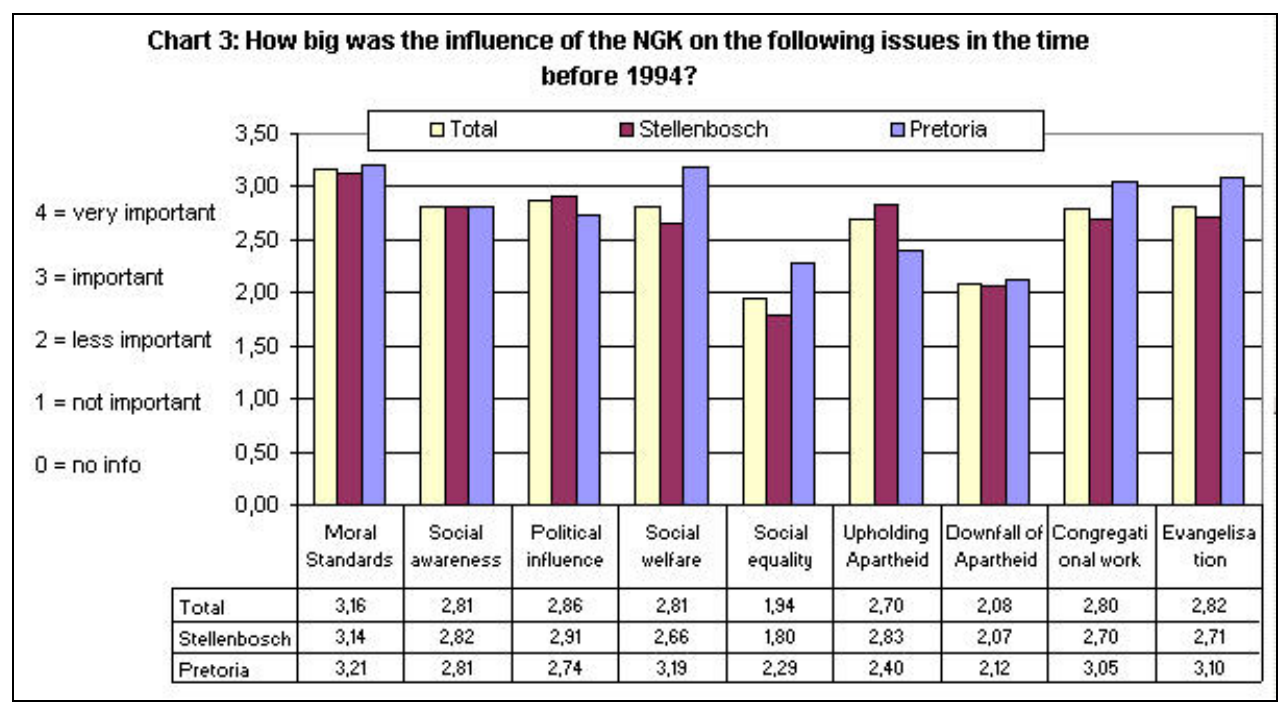

When asked to rank the importance of the work of the church during the apartheid-era we got the following results (see Chart 3). As expected the church was perceived strongly in its traditional work-fields like "Congregational work" and "Evangelisation". What was astonishing to me was that the "setting of moral standards" was perceived by the students as strongest influence of the church on the public and community, topping possibilities like the typical congregational work and social responsibilities.

Another trend that could be picked up was that many students differentiated between the DRC of the past and the present one with regard to the responsibility for apartheid. This differentiation even goes so far that $33 \%$ of the students said that it would have been better for the DRC to start all over regarding their structure and organisation after the fall of apartheid. Only $35 \%$ of the students opposed this option. Although most of the students see a political influence of the DRC in the past, only $36 \%$ of the students feel that the church should be hold responsible for the wrong-doings of apartheid. On the one hand they admit partly that the DRC of the past had a limited responsibility for the wrong-doings of apartheid, especially by not openly speaking out against it, but many do not see any direct implications out of this for the current DRC. To formulate it more drastically: many of the students have only a limited critical historic perspective regarding the role and the responsibility of the DRC in the apartheid-era. This becomes clear in the following statement:

“... Where the NGK was directly involved [in apartheid] it might have been at fault, but this is now history. People should not dig up history and "dead cows", if something is in the past it is past. FORGIVE AND FORGET!" (Male, Stellenbosch).

This attitude to "forgive and forget" is used more or less directly by several students to respond to the question of responsibility for the apartheid-legacy. It is often followed by the very pragmatic advise to "move on and look forward". 


\section{The DRC in the present and future}

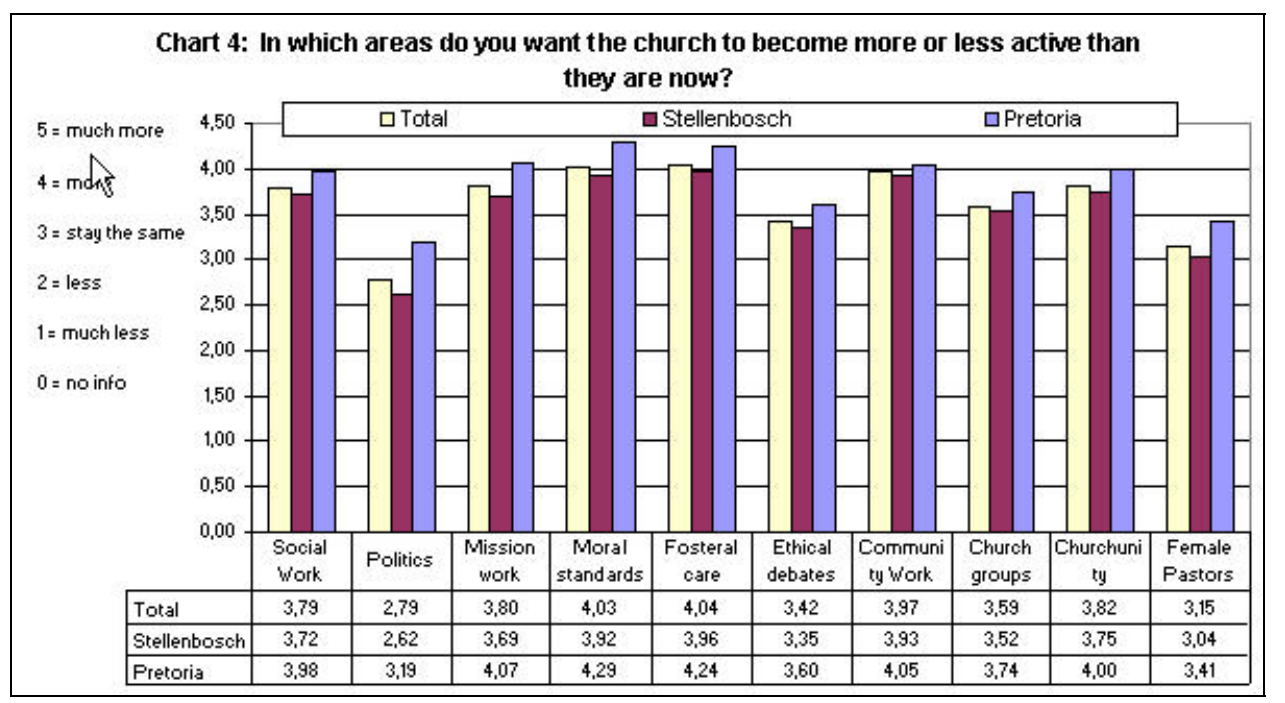

The current phase of consolidation and new orientation within the DRC is perceived positively by most of the students. More than half of the students were of the opinion that the position and influence of the DRC had positively changed towards their contribution to the broader South African society and towards the other churches in South Africa. Only under $10 \%$ of the students were of the opinion that nothing had positively changed.

The strength of the current DRC is seen in its social involvement and in the setting of social values and moral standards for the broader South African community. When asked to identify the work areas within the DRC that the students would like to be strengthened and extended the students opted especially for the social and welfare work next to the typical congregational work as well as setting social values and moral standards (see Chart 4). The influence on politics was ranked the lowest and underlines the comments in the essay questions which demand from the church to take on an apolitical stand. It was very astonishing to me that the options "development of a new theology" as well as the "participation in the ethical debate" was ranked lowest. This trend of a focus on the more practical work within the church can be summarised in a statement by a student: "Less talking, more actions!"

\section{Church-unity}

A special section of the questionnaire was dedicated to the question of church-unity within the DRC-family. The general trend that could be picked up among the students in Stellenbosch was a very positive attitude with regard to church-unity - this is in strong contrast to the results in Pretoria - although the predictions about when it would happen were relatively disillusioned. Only $31 \%$ of the students were of the opinion that the DRC will unite with its daughter-churches within the next 10 years.

It was very interesting for me to compare the answers regarding the church-unity within the DRC-family with the answers given in the open essay question regarding the special role of the DRC within South Africa. In the latter question a substantial number of students voluntarily opted for an overall unification of all Christian churches within South Africa, 
leaving aside the individual traditions and theological characteristics of the individual churches. This stood in strong contrast to only $48 \%$ of the students favouring a unification with the daughter-churches which are relatively close to the DRC itself.

\section{The reconciliation process in South Africa and the TRC}

The third block of the questionnaire referred to the general reconciliation process in South Africa and specifically to the Truth and Reconciliation Commission. Many students commented at the end of the questionnaire that they were not familiar with the TRC at all and therefore found it difficult to answer this question block. This will be taken into account for the main questionnaire that will be handed out at the end of the month where the detailed questions regarding the TRC have been down scaled.

In the question block regarding the general reconciliation in South Africa the students were asked to evaluate different statements about South Africa's past. It was very interesting that in Pretoria still close to $60 \%$ of the students stated that the basic intentions of the apartheid-ideology were "probable right" but just wrongly implemented. In Stellenbosch only $30 \%$ of the students chose this option.

A similar pattern showed with the statement that the white South Africans are still profiting from the legacy of apartheid. Over $70 \%$ of the students in Pretoria were of the opinion that this statement was false, compared to $50 \%$ of the students in Stellenbosch.

The students of both universities agreed that the apartheid-ideology was a crime against humanity and that most white South Africans had no knowledge about the crimes committed by the state.

In the question dealing with the personal feeling of guilt regarding the consequences of apartheid most of the students answered that they had "no" or only "very little" feeling of guilt. Only 3\% of the students had a strong feeling of guilt regarding the legacy of apartheid.

In the question regarding the beneficiaries of the apartheid the students named the white South Africans, the economy within South Africa, the white South African farmers and also the Afrikaner churches.

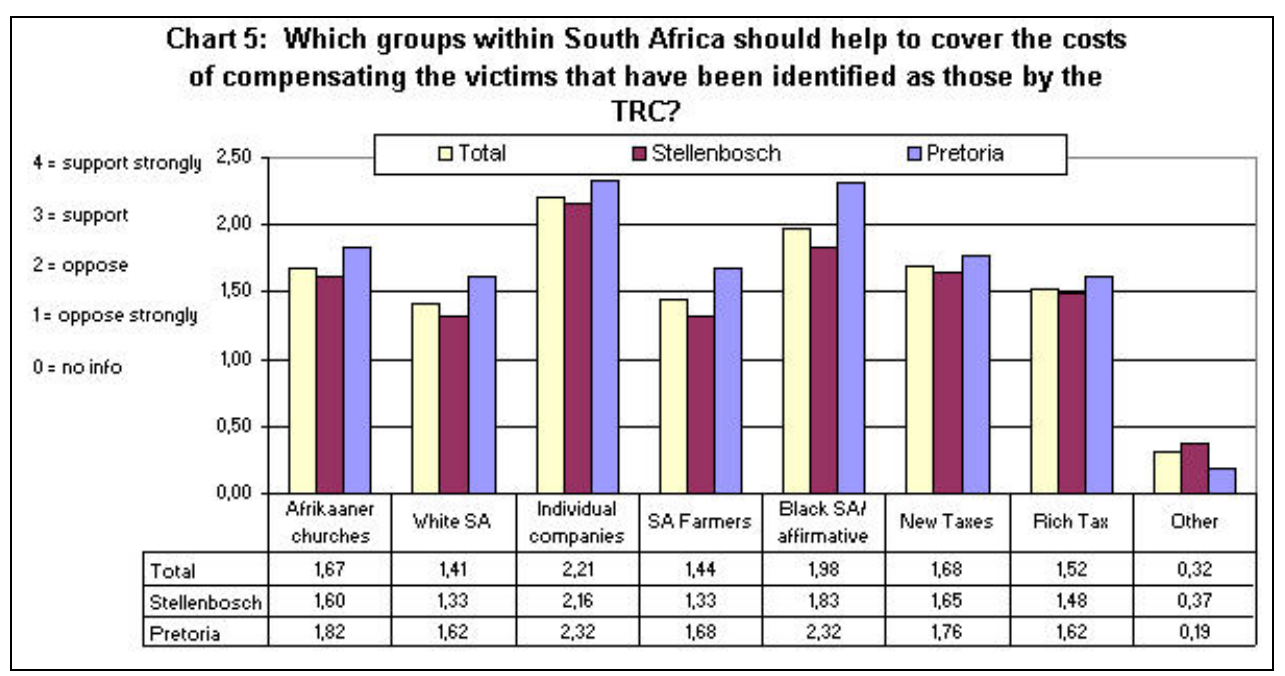


In the indirect counter question - Which groups and organisations should pay for the compensation and reparation of the victims of the apartheid-era? - we got a different answer pattern which did not correspond with the identification of the beneficiaries of apartheid (see Chart 5). The students named here single companies as well as blacks who had profited through the affirmative action program. Groups like the South African farmers or the Afrikaner-churches only got average ratings. The white South Africans in general got ranked the lowest regarding the compensation question!

It becomes evident again that the students have a certain feeling of injustice regarding apartheid but they do not draw any consequences from this for the present. To the contrary: the reparation and compensation of the victims are left to individual companies and organisations or even to the blacks themselves who were mainly the victims of the apartheid-era.

\section{The Truth and Reconciliation Commission (TRC)}

We asked the students how familiar they were with the Truth and Reconciliation Commission. 38\% of students felt themselves well informed about the TRC. When we asked more detailed information the number dropped further. Only $16 \%$ of the students felt well informed about the structures of the Commission, and $25 \%$ about the proceedings themselves and the results of the commission.

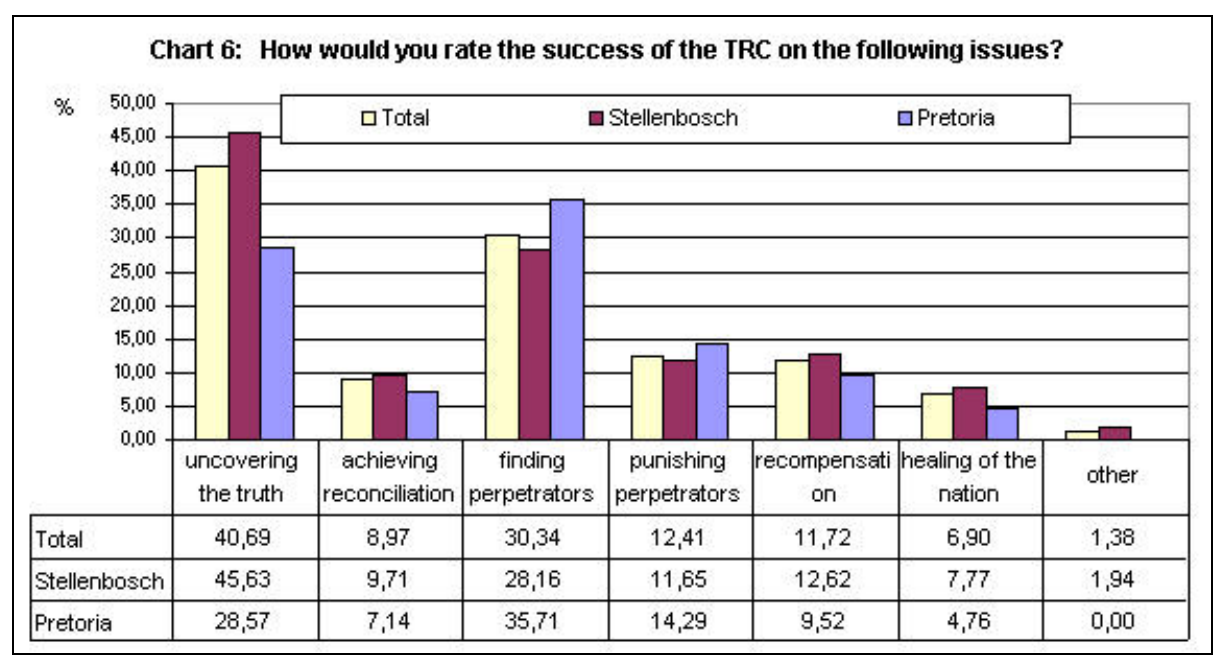

The evaluation of the relevance and the success of the TRC varies (see Chart 6 ). The primary goals of the TRC, like uncovering the truth and the finding of the perpetrators, are evaluated relatively positively. The secondary goals of the TRC, like the so-called "healing of the nation" or the establishment of reconciliation, are perceived mostly as a failure. Only $7-9 \%$ of the students saw these goals accomplished through the work of the TRC. Especially the secondary goals of the TRC require an intensive occupation with work of the TRC which - as the questionnaire has shown - the students have not done.

We can summarise that the primary work of the TRC is evaluated positively while the overall goal of the commission, the establishment of reconciliation, is perceived to have 
failed completely. But we have to keep in mind that these last results regarding the TRC were only given by $38 \%$ of the overall number of students.

\section{Selected comments}

This then was a short overview of the results of the preliminary questionnaire. Another interesting dimension would have been a comparison of the results from Stellenbosch and Pretoria. At this point I would just like to highlight certain trends that I picked up in this first evaluation and that will be followed up in the main questionnaire.

\section{- The shift of the students religiosity to a more personal and individual level}

The religiosity of the students becomes more individualised during their time at university. The external influences on the personal religiosity go down in general and the students become more mature in their belief and feel a stronger personal responsibility for their own belief. This new personal responsibility allows them also to be more critical to a certain degree towards the individual church practices. They start to differentiate much more between the individual elements and practices in the church. To say it casual: "They do not buy the entire package anymore". This new personal responsibility also allows many of the students to spread their commitment to different churches. They can visit a prayer-group in one church, a church-camp in another and attend different church-services altogether as long as they can reconcile these different experiences with their personal religiosity.

\section{- The search for orientation}

Another trend that I picked up is the search for clear standpoint regarding social norms and values. In the essay questions many students demanded from the DRC to take a clear stand on moral and social issues. This impression was also confirmed through the personal interaction with the students. Where does this come from? I believe that this can partly be explained through the tremendously risen complexity of the environment and daily life of the students. The impact that the comparatively pluralistic environment on campus has on the students is tremendous especially if they are from a relative homogeneous and secure background. This challenges them in every aspect of life. Not only the new living conditions, the complex university structures, and the daily organisation of studies and "recreation" have to be mastered but also the multitude of new contacts with fellow students and their particular perceptions and world views. All these new impressions and conditions are experienced on the one hand as a new "freedom" to experiment and broaden the own horizon. On the other hand these new conditions also bring along a certain insecurity and confusion about the own identity and self-understanding. The relative strong pluralism on campus is experienced as big challenge for the own identity and selfperception.

This entire process is complicated by the strive for individualism. It is not "political correct" anymore to easily adapt certain world views and perceptions without first evaluating them thoroughly before the own background of personal norms and values which on the other hand are not fully developed yet. Not all of the students can cope with this complex and straining process. Many end up fulfilling their claim for individuality by merely choosing a bigger interpretation framework and then adopting the easy and clear structured "black and white" world view prescribed by this framework. (This could be an explanation for part of the big attraction that the charismatic churches in South Africa have on the youth.) 
- The uncritical perception towards history

On top of this the students are "haunted" in their identity as Afrikaners by the apartheidlegacy. On the one hand they are confronted with the legacy of apartheid (e.g. "affirmative action" or scholarship policies) but on the other hand they are deprived of detailed information about it. So they cannot develop an own critical position towards this legacy. As the questionnaire has shown there is very little or no critical historic awareness regarding the apartheid-era among the students. From my point of view vital sources of information about this time-period like the Truth and Reconciliation Commission have been uncritically stigmatised as "one-sided", "bias" or even as "witch hunt" and therefore been disqualified for the students as possible sources of information. In the personal surrounding of students the topic apartheid is for many a "taboo". Parents, family and friends refuse to comment or talk about it. Also the contact to students of different ethnic descent is close to none-existent. In this regard the language policy of the University of Stellenbosch can be counterproductive because it may limit the experience of diversity which will be essential for mastering the future life in the diverse society in South Africa. As far as I know there are only a few programs implemented up to now at the university to expose the predominately white students to the diversity that South Africa has to offer. This leaves many of the students with regard to apartheid and the experience of diversity in a certain stage of innocence to put it positively and negatively in complete naivety, which will be to their disadvantage in their "survival" in the future South Africa.

\section{- The relative uncritical perception students towards the DRC}

The relative uncritical position of the students towards the past of the DRC can be explained from my point of view from their strong desire for an intact institution that can give them guidance and support. It would be not correct to say that the students were not aware of a certain involvement of the churches in the promotion and upholding of apartheid. But it seams to me that the immediate importance of the church for the students as spiritual guidance and source of moral support outweighs the historic mistakes of the DRC.

The questionnaire has shown that the students are willing to trust the DRC again under two conditions: 1 . The churches have to at least superficially correct the most obvious mistakes of the past and have to admit a certain involvement in the apartheid-era. 2. They expect now from the DRC to stay apolitical and to concentrate on their basic working areas - congregational and welfare work - and to help setting moral and social standards in society as the question regarding the future working fields of the DRC has shown.

Further it was very interesting to me how on the one hand the obvious differences among the individual Christian institutions were ignored by the students to promote the idea of a single universal united Christian church in South Africa. And then on the other hand to find partly the exact same students rejecting a unification of the DRC with its daughter-churches because they fear to loose their particular religious, cultural and traditional identity. This uncritical and utopian wish for a united Christianity in South Africa shows from my opinion the strong urge for an universal moral framework by the students.

\section{Epilogue}

In conclusion I would like to state that the DRC in South Africa still has a very strong stand among the age-group of the students. The church in general is still perceived to be one of the most important and authoritative institutions in the country. But the future role of the 
DRC will depend strongly on its capability to accommodate and support the members in their search for a new identity in the changing South Africa, and this not only among the youth. Here it will be crucial that the DRC leads them courageously into the new and diverse society South Africa's and that it does not isolate its members from this society.

\section{BIBLIOGRAPHY}

Atteslander, P 2000. Methoden der empirischen Sozialforschung. Berlin/New York: Walter de Gruyter.

Damrell, J 1978. Search for Identity. Youth, Religion and Culture. London: Sage Publications.

Dreyer, JS, Pieterse, HJC \& Ven, JA der 2001. "Religious and human rights attitudes among South African youth in a time of transformation”. In: FA. Swanepoel (ed.), Religion, morality and transformation. Pretoria: Department of Production, University of South Africa.

Rosenfeld, A 2001. "Reporting on the State of Emergency in Die Kerkbode (1985-1990)". In: Mitchell, G \& Mullen, E (eds.). Religion and the Political Imagination in a Changing South Africa. Münster/New York/München/Berlin: Waxmann.

Tallman, I, Marotz-Baden, R \& Pindas P 1983. Adolescent Socialisation in Cross-Cultural Perspective. Planning for Social Change. New York/London, Academic Press.

Tayob, A \& Weisse, W 2000. Religion and Politics in South Africa. From Apartheid to Democracy. Münster/New York/München/Berlin: Waxmann.

Wuthnow, R (ed.) 1979. The Religious Dimension. New Directions in Quantitative Research. New York/San Francisco/London: Academic Press. 